\title{
The Figure of Trickster in the Work of Andrei Tarkovsky from the Perspective of William J. Hynes's Theory
}

\author{
Natalia Różalska (D)https://orcid.org/0000-0002-2422-3909 \\ Institute for the Study of Religions \\ Jagiellonian University \\ natalia.rozalska@yahoo.com
}

\begin{abstract}
This paper is dedicated to an analysis of the figure of the trickster in the work of Andrei Tarkovsky from the perspective of William J. Hynes's theory. The paper discusses three films directed by Andrei Tarkovsky: Nostalghia (1983), The Sacrifice (1986) and Stalker (1979). The trickster is one of the oldest and most widespread mythical figures. It is characterized by a paradoxicality which serves to manifest the trickster's liminality and transformative powers resulting from the absence of divisions. Examining the selected protagonists from Tarkovsky's films, it may be seen that many of the features of the trickster are also constitutive for them. The paper works to understand why Tarkovsky chose to use the trickster figures to promote his own ideas, as well as how changes in the contemporary culture and society influence how the trickster archetype is presented in his movies.
\end{abstract}

Keywords: Trickster, Andrei Tarkovsky, Russian film, William J. Hynes

Słowa kluczowe: trickster, Andriej Tarkowski, film rosyjski, William J. Hynes

Andrei Tarkovsky is considered to be one of the most outstanding directors in the history of Russian cinematography. In his work he devoted much attention to spirituality and faith. The aim of this paper is to examine three protagonists of Tarkovsky's films and to show their resemblance to the mythological figure of the trickster understood in the terms of William Hynes' theory. The following characters will be analysed: Domenico from Nostalghia (1983), Alexander from The Sacrifice (1986) and the title character of Stalker (1979).

The trickster is one of the oldest and most widespread mythical figures. It is characterized by a paradoxicality which serves to manifest the trickster's liminality and 
transformative powers resulting from the absence of divisions. ${ }^{1}$ Claude Lévi-Strauss strongly emphasised the ambivalent nature of the trickster, considering it to be the embodiment of all complimentary oppositions. ${ }^{2}$ Victor Turner, in turn, emphasised its creational and transformational functions, claiming that this figure temporarily mixes and damages all categories in which it functions, in order to create new combinations and anomalies. ${ }^{3}$ Numerous studies consider the trickster as a variant of such figures as shaman, magus, sorcerer, mystic, holy fool, or saviour. ${ }^{4}$

Because of the nature and content of the stories in which trickster figures appear, doubts have arisen as to whether such narratives should be classified as myths, or as ordinary folk tales. However, the way in which these stories are transmitted within a given community, together with certain elements of their content, seem to indicate that the trickster stories are in fact myths. Although they are typically humorous in nature, they also contain a message that is important for the religious life of the community. The satirical, or sometimes even sacrilegious, side of the trickster's adventures is a feature not excluded from the entire scope of sacral symbolism; it is an essential part of the functioning of religious systems. Therefore, it should be recognised that the trickster figure belongs to the dimension of sacrum. ${ }^{5}$

Due to the ubiquity of the trickster figure and a range of features so wide that some of them (to varying degrees) appear in other figures, the trickster for some researchers may become a label fitting any research assumption. One solution to this problem may be the set of prototypical features proposed by William J. Hynes, which may serve as a key and criteria for the analysis of figures whose trickster status is uncertain. The list consists of:

1. An ambiguous and anomalous personality,

2. Behaviour and actions marked by cheating, deception and trickery,

3. Shape-shifting,

4. An ability to transform a given situation,

5. Functioning as a messenger or an imitator of gods, or usurping one's supernatural legitimacy in order to perform these roles,

6. A combination of sacredness and lewdness. ${ }^{6}$

Examining the selected protagonists from Tarkovsky's films it may be seen that many of the above-mentioned features of the trickster are also constitutive for all three of them.

An ambiguous and anomalous behaviour and personality are features uniting each of the analysed characters. They astonish and perplex the viewer with their ways of being and manner of expression. The eponymous Stalker, for example, often uses

${ }^{1}$ M. Eliade, W poszukiwaniu historii $i$ znaczenia religii, transl. A. Grzybek, Warszawa 1997, pp. 213-215.

2 W.J. Hynes, W.G. Doty, Mythical Trickster Figures, Alabama 1993, pp. 19-20.

${ }^{3}$ Ibidem, p. 20.

${ }^{4}$ J. Sieradzan, Szaleństwo w religiach świata, Kraków 2005, p. 96.

5 A. Szyjewski, Granice mitu, "Studia Religiologica" 2006, no. 38, p. 15.

${ }^{6}$ W.J. Hynes, Mapping the Characteristics of Mythic Tricksters: A Heuristic Guide, [in:] W.J. Hynes, W.G. Doty, op. cit., pp. 33-45. 
parable to convey information and many times communicates in such a way that his interlocutors have no idea what he is actually talking about. He usually only gives single, illogical orders with no explanation. Moreover, with his eccentric and extremely incomprehensible behaviour, Stalker causes anxiety in the community. This may be seen, for instance, in the way in which he maps out the route along the Zone. Not only does he perform it by throwing ribbon-wrapped nuts in the direction in which he intends to go, but he notoriously points to the place he and his companions are heading to and then throws the nut in a different direction. To the surprise and outrage of the others he replies that such action is necessary, as that is the will of the Zone. Domenico (Nostalghia) also uses metaphors and riddles as a means of communication. He causes astonishment among the people he meets by, for example, accosting them in the street and asking for a cigarette, although he does not smoke. Alexander (The Sacrifice), on the other hand, after going through a spiritual transformation, becomes silent, and ceases to verbally communicate with the surrounding world. What is important for further deliberations is that his silence is not a form of mortification, but an expression of the necessary quietness in the face of the unspeakable mystery of God, as Kazimierz Sobotka claims.?

Another trickster feature related to the typical demeanour of the analysed protagonists is behaviour marked by deception and trickery. Whereas in the cases of Domenico and Alexander these are small, rather inconspicuous habits strongly associated with an anomalous personality, in the case of Stalker it is a very complex deception achieved by the means of an extensive narrative of his creation. The Room into which Stalker's companions want to go (tempted by the promise of the highest happiness and fulfilment) may actually be a great illusion, a fraud of Stalker's design. His goal is to confront people with their true nature and innermost desires by guiding them on the way to self-discovery. By creating a suitable narrative and depicting the Room as a place existing in reality, Stalker lures people into his game. Asked in an interview whether the Room is a real place in the film reality, Tarkovsky gave an ambiguous answer. He stated that he was aware that the image he created allows an interpretation according to which the whole Zone was invented by Stalker as a means of putting people on the path leading to discovery of the truth about themselves, and to change their perception of reality. He also declared that he fully accepts this interpretation. ${ }^{8}$

The main task of each of the film tricksters is transforming the existing reality, which is in compliance with another Hynesian feature. Just like their mythical prototypes, the protagonists reach for all available means - no matter how controversial - of forcing people to reflect on themselves and their reality. In consequence, their actions are expected to transform the world into its better version. The most radical variant of this ability is depicted in Nostalghia and The Sacrifice. In both films, the trickster-based protagonists have the ability to save mankind and to prevent inevitable annihilation by performing one task. Such transformation of reality and

\footnotetext{
${ }^{7}$ K. Sobotka, Film i sacrum: „Ofiarowanie” Andrieja Tarkowskiego, "Łódzkie Studia Teologiczne” 1994, no. 3, p. 212.

${ }^{8}$ Andrei Tarkovsky: Interviews, J. Gianvito (ed.), Jackson 2006, p. 61.
} 
overturning of the existing order may also take place gradually, such as by working on individuals or small groups.

An example of this kind of subversion is depicted in Stalker. In the final scene the protagonist is seen as he throws himself on the floor in a gesture of despair. By the skin of his teeth, he saved the Zone from destruction, when Professor - one of Stalker's companions - decided to blow it up. He is in despair because he has devoted his entire life to guide through the Zone the unfortunate ones who, overwhelmed by despair and suffering, could find happiness and comfort only in the Zone. Stalker believes that making a change in just one person may lead to the improvement of the whole reality. When he is lying on the floor, in comes Stalker's wife, who - being his companion and understanding his vocation - tells him that his anger is unnecessary and that he should pity people and sympathise with them. The reply she receives is, at the same time, the answer to the question of why the stalkers appeared in the first place: "They know that 'they are born to some purpose'! That they 'have a calling'! [...] And nobody believes. [...] Whom should I lead in there? [...] [N]obody needs that Room. And all my efforts are worthless!" The scene shows the tragic nature of the situation the trickster has to face: the sense of meaninglessness, the inability to repair the whole world and to save people, and the fear of failing in the mission. Nevertheless, Stalker continues his work, despite being unable to prove whether his actions achieve their expected results. He is well aware that he could stop being a stalker and lead a happy and peaceful life with his family, instead of experiencing constant ostracism and suffering due to his mission. However, whenever his help is needed he takes on the role of the guide, no matter the cost.

All of Tarkovsky's cinematic trickster representations play the role of a messenger or imitator of gods, which is yet another of feature on Hynes' list. In the analysed works it is depicted in various ways. First of all, in order to become a stalker one had to experience a calling, and to be born with the abilities to come in contact with the Zone and to properly recognise its will. Furthermore, previous attempts of interpretation of Stalker's protagonist have tended to compare him with a prophet figure, or even with Christ himself. In an interview, Tarkovsky strongly agreed with this interpretation and added that Stalker is indeed a prophet who is convinced that mankind is doomed, as it has lost its spiritual life. ${ }^{10}$ The cases of Domenico and Alexander are slightly different. Neither of them had been predestined or experienced a calling to make them enter the roles they perform. They experienced a ground-breaking change in their lives, after which marked the beginning of their roles as trickster. In Domenico's case the transformation was related to the epiphany and revelation of whom he should become in order to save mankind. In The Sacrifice it may be observed that Alexander's change is a consequence of the agreement he concluded with God, which concerned accomplishing a task that would prevent mankind's annihilation. At this point, a certain intention of Tarkovsky reveals itself - the characters he created, especially Domenico and Alexander, are a specific variation of the trickster figure strongly modelled on the figure of yurodivy.

\footnotetext{
9 Stalker, dir. A. Tarkovsky, USSR 1979.

${ }^{10}$ Andrei Tarkovsky..., op. cit., p. 59.
} 
From an etymological point of view, yurodivy (юродивый) is the Old Russian term corresponding with the Greek word salós ( $\sigma \alpha \lambda o ́ s)$ and with its synonym morós

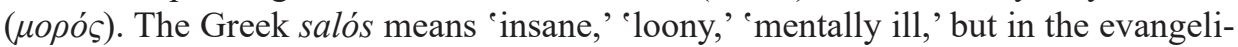
cal context it takes on a new meaning, describing a particular kind of madness - not real but simulated, faked and intentionally exposed to the public eye. In Old Russian, yurodivy colloquially meant a person suffering from mental disability. ${ }^{11}$ The term is derived from the Old Russian uroden, meaning 'miscarried foetus,' as well as 'fool by birth' or 'person that chooses to act in an eccentric way.' ${ }^{12}$ The word yurodivy may also be expressed as 'crazy,' 'stupid,' 'idiot' and 'madman.' Examining key features of this figure the following image appears: yurodivy is a mystic of a very tricksterlike nature, who answers God's call by sacrificing his/her worldly life, and assuming the role of God's tool in the process of salvation.

The internal transformation of Domenico and Alexander is in fact the moment of their entry onto the path of iurodstvo.

In Tarkovsky's tricksters four of the six features listed by Hynes may be observed:

- An ambiguous and anomalous personality,

- Behaviour and actions marked by cheating, deception and trickery,

- An ability to transform a given situation,

- Functioning as a messenger or an imitator of gods, or usurping one's supernatural legitimacy in order to perform these roles.

The features that do not occur are:

- Shape-shifting,

- A combination of sacredness and lewdness.

The absence of the last two features results from the fact that Tarkovsky was strongly inspired by the figure of yurodivy when creating his trickster characters. Had this figure possessed these features, it would have obviously ceased to be yurodivy, as its behaviour would have gone beyond the ramifications of the Eastern Orthodox Church's theology. It would have lost its status: within the culture in which it occurred it would have ceased to be a "holy fool," becoming simply a "fool."

At this point it becomes clear and intelligible why Tarkovsky used the trickster figure in every one of the discussed films. An important factor in the analysis of Tarkovsky's work is the director's perception of the cinematography as such. In his opinion, a film should directly influence emotions and actions of the viewer; it should act as a catalyst for spiritual transformations. ${ }^{13}$ As Michał Legan writes, although Tarkovsky avoids answering questions about the reality of film events, he creates his cinematic world in such a way, so as to remind people about their transcendent desire for sacrum, and about their metaphysical anxieties and inspirations. The goals of his film characters reach beyond the materiality of the world. Regardless of the time and space of action, Tarkovsky has equipped the protagonists with the desire for the absolute, purpose and sense. He has also allowed them to make religious sacrifices. ${ }^{14}$

${ }^{11}$ C. Wodziński, Św. Idiota. Projekt antropologii apofatycznej, Gdańsk 2009, pp. $20-21$.

12 J. Sieradzan, op. cit., p. 281.

${ }^{13}$ M. Legan, Balthasar/Tarkowski: teodramat w filmie. Koncepcja teodramatu w myśli teologicznej Hansa Ursa von Balthasara i twórczości filmowej Andrieja Tarkowskiego, Kraków 2012, pp. 76-77.

${ }^{14}$ Ibidem, p. 79. 
Tarkovsky constructs his yurodivy-inspired tricksters in a very oblique way. In order to speak about iurodstvo, the given phenomenon has to comply with theology of the Eastern Orthodox Church, even if it is not explicitly mentioned. In one interview, Tarkovsky admitted that to him it is not the specific denomination, but the faith itself that is crucial. He explained that over time faith may be expressed in various ways, as determined by individual experiences. However, in his opinion the most important thing is simply not to lose faith, as without it a person becomes spiritually uprooted. ${ }^{15}$

Tarkovsky's intention was to create films that are multifaceted and referring to many meanings. Therefore his aim in The Sacrifice was not to confront viewers with Christian religious experience, but only to open them to the world of spirituality, regardless of its nature. Despite his own declarations the director created his works from the standpoint of a religious person, and seems to have expected the same sensitivity to spiritual content from the viewer. As a consequence, in spite of the assurances that he wanted to evoke the experience of the drama of human fate, the whole film is somewhat immersed in Orthodox religiosity. As an example one may point to the prayer that the protagonist says, or to Christian-themed paintings, like the album of icons, that he admires. Alexander's spiritual breakthrough in the final scene is definitely of a religious nature, not existential or philosophical, as some critics of Tarkovsky's work would have it. ${ }^{16}$

Another of the discussed films, Nostalghia, openly depicts Christian religiosity, whereas Stalker in that matter is quite difficult to grasp. Despite his declarations, Tarkovsky was again unable to refrain from equipping his film with Orthodox-related elements. However, in Stalker's case these elements are much fewer than in other of the analysed works. References to this symbolism include a single abandoned icon piercing through the ruins, and fragments of conversations in which biblical stories and references to Orthodox church may be heard. Stalker's behaviour is also full of hidden meanings. As mentioned, Domenico speaks openly about religion, while Alexander initially treats religion as a source of aesthetic rather than spiritual experiences. It was not before his prayer that the viewers could witness the protagonist of The Sacrifice turning directly to God. At this point, Stalker's prayer-like behaviour is worth mentioning. It is not as obvious as Alexander's prayer, since Stalker does not use conventional forms of prayer, nor does he assume a proper posture or refer to God directly. Nevertheless, viewers may observe that his behaviour implies such practice. The first thing Stalker does after entering the Zone is to leave his companions and go to a secluded place. When he is alone, he lies in the grass facing the ground, as if immersing himself in nature. Some phenomena related to the Orthodox faith and Russian culture would be helpful in interpreting this behaviour as a practice of religious provenance. First of all, it has its roots in the primordial beliefs associated with the cult of Mother Earth. For the people of Ruthenia the cult was so significant that it was embedded into the practice of the Eastern Orthodox Church. Secondly, the common custom in Ruthenia was to lie on the ground while making vows or requesting a blessing. Moreover, quite frequently this type of behaviour was associated with

\footnotetext{
${ }_{15}$ Andrei Tarkovsky..., op. cit., p. 57.

${ }^{16}$ K. Sobotka, op. cit., p. 209.
} 
expressing repentance. This could be accompanied by kissing the ground, and in some cases, even eating it. ${ }^{17}$

On the other hand, admiring the beauty of the natural world is strongly rooted in the whole Christian tradition. The beauty of nature was supposed to be a testimony to the perfection of creation, and thus to the perfection of God. Saint Basil stated that contemplation of this beauty is the simplest way to raise the mind towards God. Contemporary philosopher Tomáš Špidlík notes that, when talking about nature, Russian philosophers move from the language of abstraction to the description of the living experience of meeting with God. Such descriptions may be found in the works of Vladimir Solovyov, Pavel Florensky and Sergei Bulgakov. ${ }^{18}$ Additionally, nature is a common motif found in Russian poetry of the nineteenth century. To Russians, it was a symbol of God's humility and Christ's Passion. It might also refer to the idea of divinization, as is the case in the work of Fyodor Tyutchev, in whose poetry nature is a space in which God's presence manifests especially strongly. ${ }^{19}$ Distancing himself and staying alone with the Zone is the first thing Stalker does when he crosses its borders. One may say, that such behaviour is, in a way, a mandatory greeting with the Zone and a request for blessing in the mission, as well as a clear sign that Stalker treats the Zone as sacrum. Stalker explicitly calls this place his real home and a holy, living mystery.

However, one should remember that despite the profound religiosity of the artist, Stalker could not openly refer to religion since the film was made in the USSR. Tarkovsky's films notoriously met severe criticism from the domestic cinematic community because of - as it was claimed - its difficult form, rawness and excessive religiosity. ${ }^{20}$ In one interview Tarkovsky stated that even though to him as an artist it is important that his films be screened in the West, what people living in the Soviet Union think about them is paramount. He said that since he lived and created in this country, the opinion of its people is extremely valuable to him. ${ }^{21}$ Of course, it should be borne in mind that the interview was conducted in 1981, before the director's emigration, so it was the only safe answer he could provide. Nevertheless, it does not change the fact that the camouflaged religiosity in Tarkovsky's films was a message to the Russians, who also had to hide their religiosity.

Stalker marks a certain borderline in Tarkovsky's oeuvre. The film opens a new chapter in the director's work in which he speaks directly about the urgent need for the restoration of mankind's spirituality. ${ }^{22}$ As the director wrote:

The progress of desacralization and the growing spiritual void resulted with the alienation of the individual from the society, the enslavement of man who lost his/her faith in the possibility

17 A.D. Sinyavsky, Ivan-Durak: Ocherk russkoy narodnoy very, Moskva 2001, p. 93.

18 T. Špidlík, Myśl rosyjska. Inna wizja człowieka, transl. J. Dembska, Warszawa 2000, p. 245.

19 E. Przybył-Sadowska, J. Sadowski, D. Urbanek, Rosja. Przestrzeń, czas i znaki, Kraków 2016, p. 18.

${ }^{20}$ M. Legan, op. cit., p. 65.

${ }^{21}$ Andrei Tarkovsky..., op. cit., p. 64.

22 S. Kuśmierczyk, Przedmowa, [in:] A. Tarkowski, Kompleks Tołstoja, Myśl o życiu, filmie i sztuce, transl. S. Kuśmierczyk, Warszawa 1989, pp. 15-17. 
of individual influence on his future, and led to the development of materialistic attitude which became, in spirituality, the basis of life. The current one-sided development of civilisation threatens the existence of humanity. ${ }^{23}$

This process, whose essential element is (as Tarkovsky claims) the cult of science and materialism in the modern world, leads to the situation in which the greatest difficulty the director's tricksters - referring to the figure of the holy fool - need to face, is the issue of mental health. In a world from which holiness, along with its mystery and inscrutability, has been eliminated, the figure of yurodivy loses its legitimacy. It was the holiness that distinguished them from madmen and justified their behaviour in people's minds. For Tarkovsky's tricksters it was difficult to achieve the status of saints in the eyes of both other characters and the viewers, because holiness itself was no longer perceived as something real.

Although the trickster may use any set of gestures, behaviours and masks, it always plays the same role. Regardless of the chosen shape, this type of mythical figure is supposed to disturb, shock, and destroy the existing reality, forcing the viewers to confront their innermost beliefs, and to accept their illusory nature. Even if that does not happen, the trickster will neither stop disturbing, nor will it cease being an unwanted, uneasy nuisance.

It is not without a reason that Tarkovsky reaches for this, and not any other figure. All the discussed films regard the problem of human functioning in the world and take into account both the material and the spiritual realities. They raise the subject of man's spiritual needs and longings. According to Claude Lévi-Strauss, it is the trickster that is the ideal mediator between the sacred and the profane, as it preserves some of the duality that it is ultimately supposed to overcome. This is the source of its ambiguous and difficult to describe nature. ${ }^{24}$ In her analysis of trickster in the context of popular culture, Joanna Puchalska also points out that in a sense the trickster is an image of human fate. ${ }^{25}$ This is probably the key reason for its great popularity and sympathy it receives from audiences, despite its controversial behaviour, which often poses a threat to others. The same was true for historical yurodivys, who were the people's favourite, even though they made their lives unpleasant. It is also because only yurodivy had the courage to point out the mistakes and weaknesses of the affluent, which no one else dared to do, although their flaws and a sense of injustice were a common experience of the people. ${ }^{26}$ Therefore the trickster, especially in its specific Russian variation as yurodivy, seems to be the most appropriate figure to be used by an artist dealing with such topics in his work. Consequently, trickster-based characters are an excellent tool in allowing Tarkovsky to present his vision of religion, spirituality and humanity itself.

Translated by Berenika Rowicka

23 A. Tarkowski, Czas utrwalony, transl. S. Kuśmierczyk, Warszawa 1991, p. 247.

${ }^{24}$ C. Lévi-Strauss, Structural Anthropology, New York 1974, pp. 224-228.

${ }_{25}$ J.K. Puchalska, Szlemy Asgardu, [in:] Trickster i inne postacie ambiwalentne w najnowszej popkulturze, A. Kuchta, J. Malita-Król (eds.), Kraków 2017.

${ }^{26}$ C. Wodziński, op. cit., p. 156. 


\section{References}

\section{Filmography}

Nostalghia, dir. A. Tarkovsky, Italy-USSR 1983.

The Sacrifice, dir. A. Tarkovsky, France-Sweden-Great Britain 1986.

Stalker, dir. A. Tarkovsky, USSR 1979.

\section{Literature}

Andrei Tarkovsky: Interviews, J. Gianvito (ed.), Jackson 2006.

Aumont J., Marie M., Analiza filmu, transl. M. Zawadzka-Strączek, Warszawa 2011.

Birzache A., The Fool for Christ: A Journey from St Paul to Pavel Lungin, "Text si discurs religios" 2012, vol. IV, pp. 293-306.

Bułgakow S., Prawosławie. Zarys nauki Kościoła prawosławnego, transl. H. Paprocki, BiałystokWarszawa 1992.

Eliade M., Sacrum i profanum, transl. R. Reszke, Warszawa 2008.

Eliade M., W poszukiwaniu historii i znaczenia religii, transl. A. Grzybek, Warszawa 1997.

Evdokimov, Prawostawie, transl. J. Klinger, Warszawa 1992.

Fiedotow G., Święci Rusi (X-VXII w.), transl. H. Paprocki, Bydgoszcz 2002.

Górka Z., Wczesnochrześcijańskie szaleństwo Chrystusowe $w$ artystycznym ujęciu Andrieja Tarkowskiego, [in:] Nowe czytanie tradycji, S. Latocha, E. Nowina-Sroczyńska (eds.), Łódź 2016, pp. 344-349.

Holy Foolishness in Russia: New Perspectives, Hunt P., Kobets S. (eds.), Bloomington 2011.

Hynes W.J., Doty W.G., Mythical Trickster Figures, Alabama 1993.

Ivanov S., Holy Fools in Byzantium and Beyond, New York 2006.

Kobets S., The Russian Paradigm of Iurodstvo, "Russian Literature" 2000, vol. XLVIII, pp. 367388.

Kozieł J., Duchowość we wczesnej twórczości Andrieja Tarkowskiego, "Acta Neophilologica" 2016, vol. XVIII, pp. 141-147.

Legan M., Balthasar/Tarkowski: teodramat w filmie. Koncepcja teodramatu w myśli teologicznej Hansa Ursa von Balthasara i twórczości filmowej Andrieja Tarkowskiego, Kraków 2012.

Lévi-Strauss C., Structural Anthropology, New York 1974.

Łosski W.N., Teologia mistyczna Kościoła Wschodniego, transl. I. Brzeska, Kraków 2007.

Madness and the Mad in Russian Culture, A. Brintlinger, I. Vinitsky (eds.), Toronto 2008.

Nowosielski J., Inność prawostawia, Białystok 1998.

Petric G.R., Tarkovsky’s Dream Imagery, "Film Quarterly” 1990, vol. 43, no. 2, pp. 28-34.

Przybył E., Prawosławie, Kraków 2000.

Przybył-Sadowska E., Sadowski J., Urbanek D., Rosja. Przestrzeń, czas i znaki, Kraków 2016.

Puchalska J.K., Szlemy Asgardu, [in:] Trickster i inne postacie ambiwalentne w najnowszej popkulturze, A. Kuchta, J. Malita-Król (ed.), Kraków 2017.

Redwood T., Andrei Tarkovsky's Poetics of Cinema, Newcastle-upon-Tyne 2010.

Sieradzan J., Szaleństwo w religiach świata, Kraków 2005.

Sobotka K., Film i sacrum: „, Ofiarowanie” Andrieja Tarkowskiego, „Łódzkie Studia Teologiczne” 1994, no. 3, pp. 207-214.

Szyjewski A., Granice mitu, "Studia Religiologica" 2006, no. 38, pp. 9-27.

Špidlík T., Myśl rosyjska. Inna wizja człowieka, transl. J. Dembska, Warszawa 2000.

Špidlík T., Wielcy mistycy rosyjscy, transl. J. Dembska, Kraków 1996.

Tarkowski A., Czas utrwalony, transl. S. Kuśmierczyk, Warszawa 1991.

Tarkowski A., Dzienniki, transl. S. Kuśmierczyk, Warszawa 1998. 
Tarkowski A., Kompleks Totstoja. Myśl o życiu, filmie i sztuce, transl. S. Kuśmierczyk, Warszawa 1989.

Thomas A., The Holy Fools: A Theological Enquiry, May 2009.

Wodziński C., Św. Idiota. Projekt antropologii apofatycznej, Gdańsk 2009.

Żyłko B., Semiotyka kultury, Gdańsk 2010. 